Research Article

\title{
Effect of Stirring Time on Sodium Silicate Synthesis from Mount Kelud Volcanic Ash
}

\author{
Isna Nurhidayati ${ }^{1,2}$, Endang Tri Wahyuni ${ }^{2}$, Nurul Hidayat Aprilita² ${ }^{2}$ Sarwendah Ratnawati Hermanto ${ }^{3}$ \\ ${ }^{1}$ Department of Analytical Chemistry, Politeknik AKA Bogor, Jl. Pangeran Sogiri No. 283, Tanah Baru, Bogor Utara, Kota \\ Bogor, Jawa Barat, Indonesia, 16154 \\ 2 Department of Chemistry, Faculty of Mathematics and Natural Sciences, Universitas Gadjah Mada, Sekip Utara Bulaksumur \\ 21, Yogyakarta, Indonesia, 55281 \\ 3Politeknik Negeri Ketapang, Jl. Rangga Sentap - Dalong, Kabupaten Ketapang, Kalimantan Barat, 78813
}

\section{ARTICLE INFO $\quad$ ABSTRACT}

\section{Article History}

Received 9 June 2021

Revised 23 September 2021

Online available 26 November 2021

\footnotetext{
* Coresponding author:
} endang_triw@ugm.ac.id

\begin{abstract}
This study synthesized sodium silicate from the volcanic ash of Mount Kelud with various stirring times in the sodium silicate synthesis process. Synthesis of sodium silicate was carried out by alkaline extraction at low temperatures. This method was based on the solubility of silica under alkaline conditions. The dissolution of silica $\left(\mathrm{SiO}_{2}\right)$ in the volcanic ash of Mount Kelud was extracted using $\mathrm{NaOH}$ solution to form sodium silicate $\left(\mathrm{Na}_{2} \mathrm{SiO}_{3}\right)$. The effect of stirring time on dissolved silica concentration was conducted with variation times of $0.5 ; 1 ; 1.5 ; 2 ; 2.5 ; 3$, and $4 \mathrm{~h}$ using AAS (Atomic Absorption Spectrometry). The amount of dissolved silica increased sharply with the longer stirring time; however, the dissolution of silica was slow for a stirring time of more than 2.5 hours. The optimum of dissolved silica $\left(\mathrm{SiO}_{2}\right)$ was $19.82 \%$ at a stirring time of $2.5 \mathrm{~h}$. The concentration of dissolved silica was very low because of semicrystalline silica and aluminium oxide in volcanic ash.
\end{abstract}

Keywords: volcanic ash, silica, sodium silicate, stirring time

\section{Introduction}

As an archipelagic state situated at the meeting point of three tectonic plates (Eurasian, Indo- Australian, and Pacific plates), the continuous movement of the plates makes Indonesia prone to natural disasters, such as tectonic earthquakes, volcanic earthquakes, and tsunamis. Moreover, Indonesia is one of the countries located in the ring of fire and has many active volcanoes. Lava flows, the release of gases, tephra, and ashfall from volcanoes can endanger humans. Volcanic eruption leads to huge losses of property, crop, plantation, and water sources damage. The disaster can cause fatalities, mainly the residents living alongside volcanoes.

Mount Kelud is an active volcano located on the border of Kediri, Blitar, and Malang Regencies in East Java Province, which produces explosive eruptions [1]. The volcanic materials of Mount Kelud eruption on February 13, 2014, thrown to other areas outside East Java. This eruption is the largest eruption of Mount Kelud that occurred in the $21^{\text {st }}$ century [2]. Lava flows and material released from Mount Kelud in 2014 had caused volcanic ash rain in several places outside East Java, such as in Solo and Yogyakarta [3]. The volcanic ash carried by the wind and reached Yogyakarta caused pollution of water sources, disturbed vision, and health problems.

Many studies have been conducted regarding the impact of volcanic eruptions on the agricultural and fisheries sectors. However, research related to the utilization of Mount Kelud's volcanic ash has not been studied intensively. In general, ash or material from volcanic eruptions, such as Mount Kelud, contains oxides of several metal elements, such as $\mathrm{Si}, \mathrm{Al}, \mathrm{Fe}$, $\mathrm{Ca}, \mathrm{Mg}, \mathrm{Na}, \mathrm{K}$, and $\mathrm{P}[4,5,6]$. The volcanic ash's silica oxide $\left(\mathrm{SiO}_{2}\right)$ content, such as sodium silicate $\left(\mathrm{Na}_{2} \mathrm{SiO}_{3}\right)$, makes it a potential alternative for making silica-based products. Silica can be derived from precursors, such as tetraethyl orthosilicate (TEOS) and tetramethyl orthosilicate (TMOS). The use of TEOS and TMOS precursors is considered relatively expensive 
$[7,8]$. Those alkyl orthosilicates are the most commonly used silica source. Because TEOS and TMOS are flammable materials and have difficulties handling and storage, it needs to explore alternative sources of silica [9]. Apart from synthetic results, silica oxide can also be obtained from volcanic ash with a relatively high concentration. In the previous report, the volcanic ash of Mount Kelud has silica oxide of $55.19 \%$ [10].

Volcanic ash expelled abundantly from the earth's bowels during volcanic eruptions. The high levels of silicate oxide in the volcanic ash of Mount Kelud make it a potential source of silica oxide. Sodium silicate is also known as an alternative silica source $[11,12,13]$. Commercial preparation of sodium silicate solutions can be achieved by reacting $\mathrm{SiO}_{2}$-containing material such as quartz sand with carbonates or sulfates of alkali metals at temperatures exceeding $1300^{\circ} \mathrm{C}$, with subsequent dissolution in the water below $200^{\circ} \mathrm{C}$ for several hours [14]. This synthesis route is energy-intensive and generates carbon dioxide and sulfur trioxide emissions that must be managed [15]. Therefore, developing a simple and low-energy method for the production of sodium silicate solutions is needed. This paper demonstrated silicon extraction for the production of sodium silicate solution as a silica oxide source.

\section{Materials and Methods}

\subsection{Materials}

This study used the volcanic ash of Mount Kelud eruption on February 13, 2014 carried by the wind and reached Pogung Kidul, Sinduadi, Mlati, Sleman, Yogyakarta. Some chemicals used are $\mathrm{HCl} 37 \%$ p.a (Merck), $\mathrm{NaOH}$ p.a (Merck), Whatman 42 filter paper (Merck), and universal indicators (Merck).

\subsection{Volcanic Ash Characterization}

The characterization of volcanic ash to determine the chemical and mineral compositions was conducted using XRF and XRD spectroscopy. X-ray spectroscopy was performed by an X-ray diffractometer (XRD) of Shimadzu type 6000X, while fluorescence spectroscopy was carried out by the Bruker S2 Ranger Spectrophotometer.

\subsection{Volcanic Ash Preparation}

Volcanic ash was washed by soaking and decantation. Afterward, the ash was dried under the sun. The dried ash was crushed and then sieved with a 250 mesh sieve to obtain volcanic ash with a homogeneous size.

\subsection{Synthesis of Sodium Silicate}

Sodium silicate synthesis was conducted by stirring 5 grams of volcanic ash with $30 \mathrm{~mL}$ of $6 \mathrm{M} \mathrm{HCl}$ solution for 2 hours. This step aims to remove elements as impurities from the solid waste material. The ash was filtered using filter paper, and the residue was washed with distilled water until it became neutral, then dried in the oven. The dried ash was added with $30 \mathrm{~mL}$ of $5 \mathrm{M} \mathrm{NaOH}$ solution. The mixture was heated up to $\pm 95^{\circ} \mathrm{C}$, and stirred with varying stirring times, namely for $0.5 ; 1 ; 1.5 ; 2 ; 2.5 ; 3$ and 4 hours. The purpose of this step is to extract silica in the volcanic ash as a sodium silicate solution. The cooled sodium silicate solution was filtered off to separate from the solid. The filtrate was put into a plastic bottle, then analyzed using an atomic absorption spectrophotometer (AAS) to determine its Si content.

\subsection{Determination of Silica Concentration}

The silica in the sodium silicate solution was analyzed by AAS (the Perkin Elmer brand type 3110). Sodium silicate solution with various stirring times was diluted into $50 \mathrm{~mL}$ of volumetric flask. The standard curve is made by diluting $\mathrm{Si}$ standard solution at a concentration of $0,20,40,60,80$, and $100 \mathrm{ppm}$. The concentration of $\mathrm{Si}$ was calculated by its absorbance on the corresponding standard curve. According to Proust's Law, the concentration of silica $\left(\mathrm{SiO}_{2}\right)$ was calculated by the ratio of molecular weight.

\section{Result and Discussion}

\subsection{Analysis of Mount Kelud Volcanic Ash}

The analysis was conducted to determine the chemical and mineral composition of the volcanic ash of Mount Kelud by using XRF and XRD methods, respectively. The results of XRF analysis was shown in Table 1, which indicated that the metal oxides of the volcanic ash of Mount Kelud was dominated by silica $\left(\mathrm{SiO}_{2}\right)$ of $56.29 \%$, followed by $\mathrm{Al}_{2} \mathrm{O}_{3}$ and $\mathrm{Fe}_{2} \mathrm{O}_{3}$. The diffraction pattern of the volcanic ash of Mount Kelud was shown in Figure 1. Sharp peaks were apparent at various angles of $2 \theta$ with various intensities. The $2 \theta$ sample data were converted into d values according to Bragg's law. Identification was carried out by comparing $d$ samples with $d$ standards as presented in Table 2. It can be seen that the main mineral content of the volcanic ash of Mount Kelud was silica $\left(\mathrm{SiO}_{2}\right), \mathrm{Al}_{2} \mathrm{O}_{3}$ and $\mathrm{Fe}_{2} \mathrm{O}_{3}$. These results was supported 
by the XRF analysis (Table 1). The volcanic ash of Mount Kelud containing a high silica composition makes it a potential alternative raw material for the manufacture of several silica-based compounds, such as silica gel and sodium silicate [16].

Table 1. The Composition of Volcanic Ash Oxides of Mount Kelud

\begin{tabular}{ccc}
\hline No & Oxide Compounds & Composition (\%) \\
\hline 1 & $\mathrm{SiO}_{2}$ & 56.29 \\
2 & $\mathrm{Al}_{2} \mathrm{O}_{3}$ & 15.65 \\
3 & $\mathrm{Fe}_{2} \mathrm{O}_{3}$ & 10.90 \\
4 & $\mathrm{CaO}$ & 9.91 \\
5 & $\mathrm{MgO}$ & 2.49 \\
6 & $\mathrm{~K}_{2} \mathrm{O}$ & 1.56 \\
7 & $\mathrm{TiO}_{2}$ & 1.01 \\
8 & $\mathrm{P}_{2} \mathrm{O}_{5}$ & 0.66 \\
9 & $\mathrm{SO}_{3}$ & 0.49 \\
10 & $\mathrm{Cl}$ & 0.44 \\
\hline
\end{tabular}

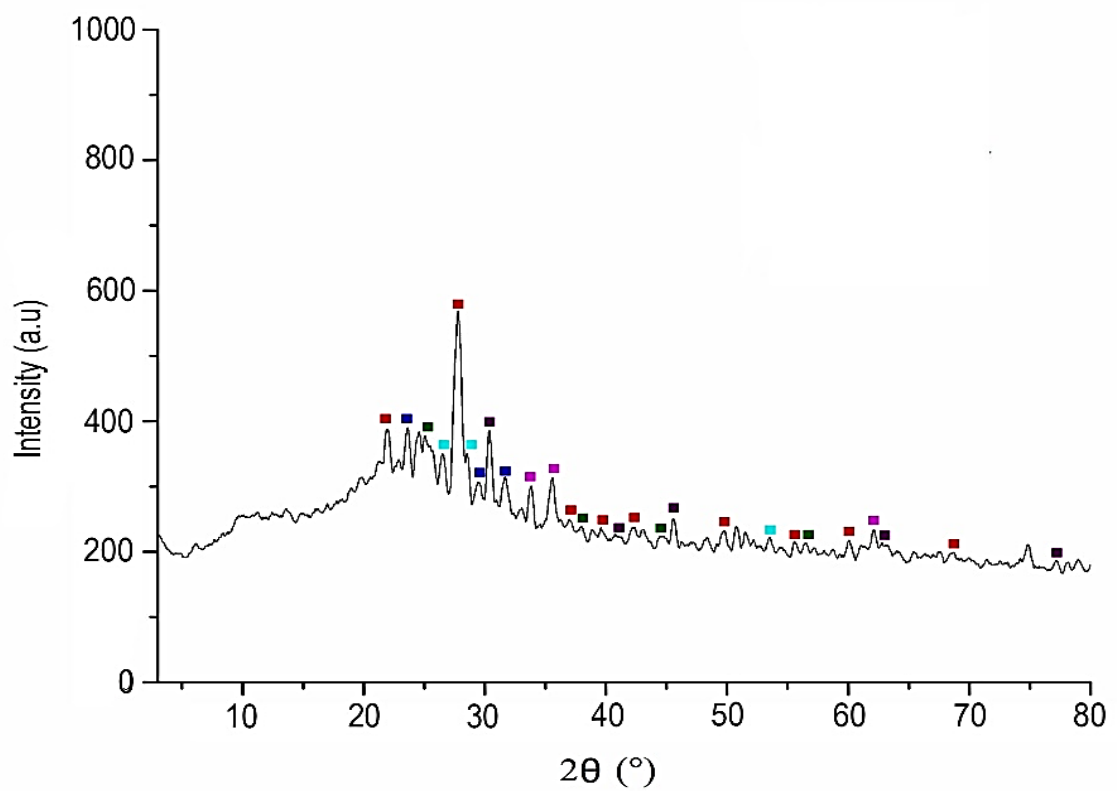

Figure 1. Diffractogram of Mount Kelud's volcanic ash : $\mathrm{SiO}_{2}$ quartz $(\square), \mathrm{SiO}_{2}$ stishovite ( $\square$ ), $\mathrm{SiO}_{2}$ coesite $(\square), \mathrm{SiO}_{2}$ christobalite $(\square), \mathrm{Al}_{2} \mathrm{O}_{3}$ diaspore $(\square), \mathrm{Fe}_{2} \mathrm{O}_{3}$ hematite $(\square)$

\subsection{Sodium Silicate Solution Preparation}

The aim of washing of volcanic ash using $6 \mathrm{M} \mathrm{HCl}$ solution is to dissolve other oxides besides silica $\left(\mathrm{SiO}_{2}\right)$. The dissolution reaction of metal oxides with $\mathrm{HCl}$ is shown in Equation 1, 2, and 3 [17].

$$
\begin{gathered}
\mathrm{K}_{2} \mathrm{O}+2 \mathrm{HCl} \rightarrow 2 \mathrm{KCl}+\mathrm{H}_{2} \mathrm{O} \\
\mathrm{Fe}_{2} \mathrm{O}_{3}+6 \mathrm{HCl} \rightarrow 2 \mathrm{FeCl}_{3}+3 \mathrm{H}_{2} \mathrm{O} \\
\mathrm{CaO}+2 \mathrm{HCl} \rightarrow 2 \mathrm{CaCl}_{2}+\mathrm{H}_{2} \mathrm{O}
\end{gathered}
$$

The preparation of sodium silicate has been carried out by several previous researchers. Sodium silicate as a source of silica $\left(\mathrm{SiO}_{2}\right)$ can be obtained from rice husk ash by dissolving rice husk ash with $\mathrm{NaOH}[18,19]$. According to Equation 4 , dissolution of silica from rice husk ash with $\mathrm{NaOH}$ produces sodium silicate $\left(\mathrm{Na}_{2} \mathrm{SiO}_{3}\right)[20,21]$.

$$
\mathrm{NaOH}+\mathrm{SiO}_{2} \rightarrow \mathrm{Na}_{2} \mathrm{SiO}_{3}+\mathrm{H}_{2} \mathrm{O}
$$

In the preparation, silica in the volcanic ash was dissolved using $\mathrm{NaOH}$ solution with heating and stirring. This method was referred to Kalapathy et al. with modification [22]. The dissolving of silica with $\mathrm{NaOH}$ solution was influenced by several factors, such as $\mathrm{NaOH}$ concentration, extraction time, and solid/solution ratio [23]. Therefore, this study analyzed the effect of stirring time on the amount of dissolved silica. 
The aims of stirring were to homogenize the solution and regulate silica extraction in volcanic ash by $\mathrm{NaOH}$. The stirring range was carried out with time variations of $0.5-2.5 \mathrm{~h}$. The effect of stirring on silica dissolution can be seen in Figure 2. It showed that the longer the stirring time, the greater of silica solubility. However, the solubility of silica was very slow for the stirring time of more than $2.5 \mathrm{~h}$. Based on the experiment, the optimal stirring time was at $2.5 \mathrm{~h}$ with silica $\left(\mathrm{SiO}_{2}\right)$ solubility of $19.82 \%$.

Table 2. Types of Volcanic Ash Crystals of Mount Kelud

\begin{tabular}{|c|c|c|c|}
\hline $2 \theta$ Sample (deg) & d Sample $(\AA ̊ A)$ & d Standard $(\AA)$ & Standard Crystal Types \\
\hline 21.200 & 4.1875 & 4.26 & \multirow{4}{*}{$\begin{array}{l}\mathrm{SiO}_{2} \text { quartz } \\
\text { (JCPDS 5-0490) }\end{array}$} \\
\hline 27.743 & 3.212 & 3.343 & \\
\hline 49.647 & 1.834 & 1.817 & \\
\hline 60.015 & 1.540 & 1.541 & \\
\hline 30.365 & 2.941 & 2.959 & \multirow{3}{*}{$\begin{array}{l}\mathrm{SiO}_{2} \text { stishovite } \\
\text { (JCPDS 15-26) }\end{array}$} \\
\hline 45.565 & 1.989 & 1.981 & \\
\hline 62.76 & 1.479 & 1.478 & \\
\hline 25.640 & 3.471 & 3.43 & \multirow{3}{*}{$\begin{array}{l}\mathrm{SiO}_{2} \text { coesite } \\
\text { (JCPDS 14-654) }\end{array}$} \\
\hline 28.480 & 3.131 & 3.09 & \\
\hline 53.455 & 1.712 & 1.71 & \\
\hline 21.860 & 4.062 & 4.05 & \multirow{3}{*}{$\begin{array}{l}\mathrm{SiO}_{2} \text { christobalite } \\
\text { (JCPDS 11-695) }\end{array}$} \\
\hline 29.426 & 3.032 & 3.14 & \\
\hline 31.620 & 2.826 & 2.841 & \\
\hline $\begin{array}{l}\text { Widened peak } \\
20-30\end{array}$ & & & $\mathrm{SiO}_{2}$ amorf \\
\hline 22.860 & 3.887 & 3.99 & \multirow{3}{*}{$\begin{array}{l}\mathrm{\beta}_{-} \mathrm{Al}_{2} \mathrm{O}_{3} \cdot \mathrm{H}_{2} \mathrm{O} \text { (diaspore) } \\
\text { (JCPDS 5-355) }\end{array}$} \\
\hline 38.800 & 2.315 & 2.317 & \\
\hline 44.665 & 2.027 & 2.077 & \\
\hline 33.772 & 2.651 & 2.69 & \multirow{3}{*}{$\begin{array}{l}\mathrm{Fe}_{2} \mathrm{O}_{3} \text { (hematite) } \\
\text { (JCPDS 13-534) }\end{array}$} \\
\hline 35.505 & 2.526 & 2.51 & \\
\hline 62.07 & 1.494 & 1.484 & \\
\hline
\end{tabular}

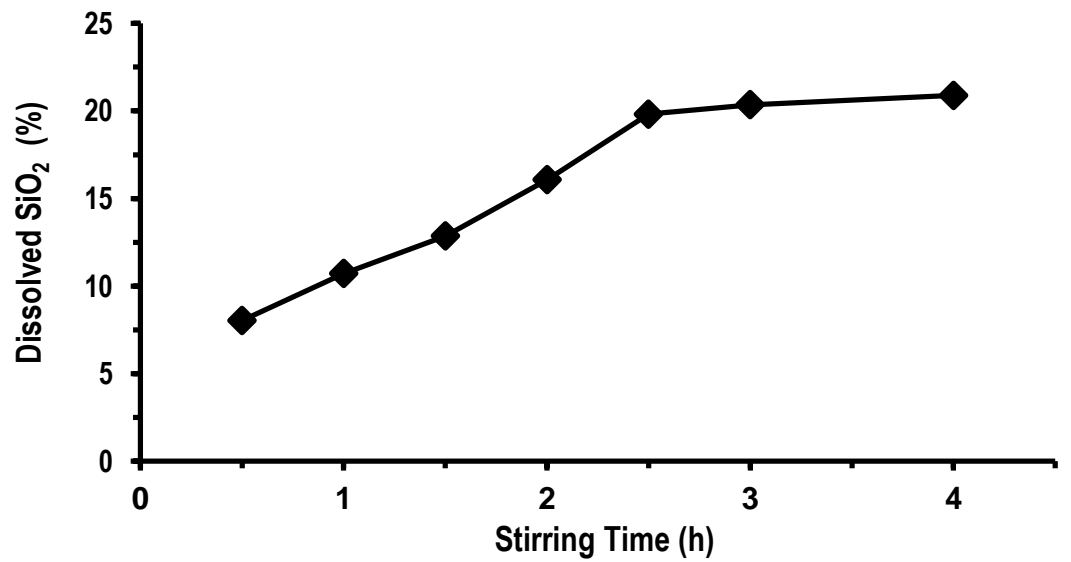

Figure 2. Effect of stirring time on the amount of dissolved silica

The solubility of silica occurred because of the reaction between $\mathrm{NaOH}$ and silica $\left(\mathrm{SiO}_{2}\right)$ in volcanic ash to make sodium silicate solution $\left(\mathrm{Na}_{2} \mathrm{SiO}_{3}\right)$. Stirring time showed the reaction time between silica and $\mathrm{NaOH}$. The increase in stirring time caused an increase in the reaction time between $\mathrm{SiO} 2$ in volcanic ash and $\mathrm{NaOH}$, resulting in a larger amount of silica solubility. For a stirring time of more than 2.5 hours, the amount of dissolved silica was relatively high enough. It was followed by reducing the contact between $\mathrm{NaOH}$ and silica and causing the amount of soluble silica to be relatively constant. Based on these data, the optimal stirring time was $2.5 \mathrm{~h}$.

The amount of dissolved silica was relatively small, and it might cause silica in the volcanic ash in semi-crystalline form (Figure 1), making it difficult to extract. Amorphous silica in various conditions is more reactive than crystalline silica. Aluminium oxide $\left(\mathrm{Al}_{2} \mathrm{O}_{3}\right)$ in volcanic ash also dissolved in the $\mathrm{NaOH}$ to form impure sodium silicate.Low dissolved silica could be caused by impure sodium silicate. 


\section{Conclusion}

Mount Kelud volcanic ash can be used to manufacture silica-based materials, such as sodium silicate. The synthesis of sodium silicate from the volcanic ash using the alkaline extraction method was considered more economical because it did not require high temperatures. The results showed that stirring time influenced the silica extraction. The longer the stirring time, the longer the reaction between silica in volcanic ash and $\mathrm{NaOH}$, which results in a greater amount of dissolved silica. Crystalline silica in volcanic ash caused the dissolved silica to be relatively low. Based on the experiment, the optimum stirring was at 2.5 hours with dissolve silica $\left(\mathrm{SiO}_{2}\right)$ of $19.82 \%$.

\section{References}

[1] A. Zaennudin, "Prakiraan Bahaya Erupsi Gunung Api Kelud," Bulletin Vulkanologi dan Bencana Geologi, vol. 4, no. 2, pp. 1-17, 2009.

[2] Badan Nasional Penanggulangan Bencana, Info Bencana: Informasi Kebencanaan Bulanan Teraktual. Jakarta: PusdatinKK, 2014.

[3] A. Heriwaseso, S. D. Andreastuti, A. Budianto, I. Santoso, Y. Kristiawan, M. C. Natalia, Khoirul, Budi, Kuncoro, \& Dani "Karakter Erupsi Kelud 2014, Pembelajaran dalam Mitigasi Infrastruktur di Kawasan Rawan Bencana," dalam Prosiding Seminar Nasional Kebumian Ke-10, 2017, pp. 1314-1332.

[4] B. W. Christenson, "Geochemistry of Fluids Associated with the 1995-1996 Eruption of Mt. Ruapehu, New Zealand: Signatures and Processes in the Magmatic-Hydrothermal System," Journal of Volcanology and Geothermal Research, vol. 97, no. 1-4, pp. 1-30, 2000.

[5] D. B. Smith, R. A. Zielinski, H. E. Taylor, \& M. B. Sawyer, "Leaching Characteristics of Ash from the May 18, 1980, Eruption of Mount St. Helens Volcano, Washington," Bulletin Volcanologique, vol. 46, no. 2, pp. 103-124, 1983.

[6] J. V. Wright \& R. A. F. Cas, Volcanic Successions Modern and Ancient: a Geological Approach to Processes, Products, and Successions. London: Chapman \& Hall, 1988.

[7] A. S. Dorcheh \& M. H. Abbasi, "Silica Aerogel; Synthesis, Properties and Characterization," Journal of Materials Processing Technology, vol. 199, no. 1-3, pp. 10-26, 2008.

[8] M. H. Razali, M. N. Ahmad-Fauzi, A. R. Mohamed, \& S. Sreekantan, "Physical Properties Study of $\mathrm{TiO}_{2} \mathrm{Nanoparticle}$ Synthesis via Hydrothermal Method using $\mathrm{TiO}_{2}$ Microparticles as Precursor," Advanced Materials Research, vol. 772 , pp. 365-370, 2013.

[9] P. B. Sarawade, J.-K. Kim, A. Hilonga, \& H. T. Kim, "Preparation of Hydrophobic Mesoporous Silica Powder with a High Specific Surface Area by Surface Modification of a Wet-Gel Slurry and Spray-Drying," Powder Technology, vol. 197, no. 3, pp. 288-294, 2010.

[10] Sukarman \& A. Dariah, Tanah Andosol di Indonesia, Karakteristik, Potensi, Kendala dan Pengelolaannya untuk Pertanian. Bogor: Balai Besar Penelitian dan Pengembangan Sumberdaya Lahan Pertanian, 2014.

[11] M. A. Rida \& F. Harb, "Synthesis and Characterization of Amorphous Silica Nanoparticles from Aqueous Silicates using Cationic Surfactants," Journal of Metals, Materials, and Minerals, vol. 24, no. 1, pp. 37-42, 2014.

[12] U. Zulfiqar, T. Subhani, \& S. W. Husain, "Synthesis of Silica Nanoparticles from Sodium Silicate under Alkaline Conditions," Journal of Sol-Gel Science and Technology, vol. 77, no. 3, pp. 753-758, 2016.

[13] C. L. Nistor, R. Lanchis, M. Ghiurea, C.-A. Nicolae, C.-I. Spataru, D. C. Culita, J. P. Cusu, V. Fruth, F. Oancea, \& D. Donescu, "Aqueous Dispersions of Silica Stabilised with Oleic Acid Obtained by Green Chemistry," Nanomaterials, vol. 6, no. 1(9), 2016.

[14] V. V. Bagramyan, A. A. Sarkisyan, C. Ponzoni, R. Rosa, \& C. Leonelli, "Microwave-Assisted Preparation of SodiumSilicate Solutions from Perlite," Theoretical Foundations of Chemical Engineering, vol. 49, no. 5, pp. 731-735, 2015.

[15] M. Fertani-Gmati, K. Brahim, I. Khattech, \& M. Jemal, "Thermochemistry and Kinetics of Silica Dissolution in $\mathrm{NaOH}$ Solutions: Effect of the Alkali Concentration," Thermochimica Acta, vol. 594, pp. 58-67, 2014.

[16] S. R. Kamath \& A. Proctor, "Silica Gel from Rice Hull Ash: Preparation and Characterization," Cereal Chemistry, vol. 75, no. 4, pp. 484-487, 1998.

[17] D. P. I. Pratomo, S. Wardhani, \& D. Purwonugroho, "Pengaruh Teknik Ekstraksi dan Konsentrasi HCl dalam Ekstraksi Silika dari Sekam Padi untuk Sintesis Silika Xerogel," Kima Student Journal, vol. 2, no. 1, pp. 358-364, 2013.

[18] P. Klankaw, C. Chawengkijwanich, N. Grisdanurak, \& S. Chiarakorn, "The Hybrid Photocatalyst of $\mathrm{TiO}_{2}-\mathrm{SiO}_{2} \mathrm{Thin}$ Film Prepared from Rice Husk Silica," Superlattices and Microstructures, vol. 51, no. 3, pp. 343-352, $2012 .$.

[19] H. B. Yener \& Ş. S. Helvaci, "Effect of Synthesis Temperature on the Structural Properties and Photocatalytic Activity of $\mathrm{TiO}_{2} / \mathrm{SiO}_{2}$ Composites Synthesized using Rice Husk Ash as a $\mathrm{SiO}_{2}$ Source," Separation and Purification Technology, vol. 140, pp. 84-93, 2015.

[20] D. Mittal, "Silica from Ash," Resonance, vol. 2, no. 7, pp. 64-66, 1997. 
[21] R. R. Zaky, M. M. Hessien, A. A. El-Midany, M. H. Khedr, E. A. Abdel-Aal, \& K. A. El-Barawy, "Preparation of Silica Nanoparticles from Semi-Burned Rice Straw Ash," Powder Technology, vol. 185, no. 1, pp. 31-35, 2008.

[22] U. Kalapathy, A. Proctor, \& J. Shultz, "A Simple Method for Production of Pure Silica from Rice Hull Ash," Bioresource Technolgy, vol. 73, no. 3, pp. 257-262, 2000.

[23] I. U. Haq, K. Akhtar, \& A. Malik, "Effect of Experimental Variables on the Extraction of Silica from the Rice Husk Ash," Journal of the Chemistry Society of Pakistan, vol. 36, no. 3, pp. 382-387, 2014. 